\title{
The Influence of Colonic Irrigation on Human Intestinal Microbiota
}

\author{
Yoko Uchiyama-Tanaka \\ Yoko Clinic \\ Japan
}

\section{Introduction}

It has been documented that the intestinal tract is inhabited by more than $10^{12}$ bacterial cells per gram of dry matter (Hayashi et al., 2002a; Langendijk et al., 1995; Suau et al., 1999), which is comprised of an estimated 400 to 500 bacterial species (Moor \& Holdeman, 1974). The composition and activities of the indigenous intestinal microbiota are of paramount importance in human immunity, nutrition, and pathological processes, and therefore, the health of the individual (Van der Waaij et al., 1971). It is well established that the intestine is an important site of local immunity, and recent reports have suggested that it is a major site of extrathymic T cell differentiation (Cerf-Bensussan et al., 1985; Guy-Grand et al., 1991; Iiai eta al., 2002; Uchiyama-Tanaka, 2009). Numerous activated and quiescent lymphocytes are produced within gut-associated lymphatic tissues (GALT), such as Peyer's patches (Takahashi et al., 2005). Thus, it has been speculated that people who suffer from constipation and who harbor fecal residues in the intestine may have decreased local immune system function.

Colonic irrigations referred to as a colonics are a type of colonic hydrotherapy performed using an instrument in combination with abdominal massage, but without drugs or mechanical pressure. I previously reported that colonic irrigation may induce lymphocyte transmigration from GALT into the circulation, which may improve the functions of both the colon and immune system (Uchiyama-Tanaka, 2009). Colonic irrigation was developed about 40 years ago and no serious complications associated with its use have been reported. However, the impact of this method, which use a large amount of water, on the intestinal microbiota and serum electrolytes remains unknown. In this study, colonic irrigations were performed 3 times for each of the 10 subjects with no history of malignant or inflammatory disease.

\section{Materials and methods}

\subsection{Study design and subjects}

The procedures used in this study were in accordance with the guidelines of the Declaration of Helsinki for Human Experimentation, 2000 and all subjects provided informed consent. Ten outpatients from the Yoko Clinic ( 4 men and 6 women; mean age $=38 \pm 6$ years; age range: 27-47 years) admitted to the hospital between April and May 2009 were enrolled in this study. None of the subjects had cancer or any active inflammatory disease. 


\subsection{Analysis of fecal microbiotauction}

Fecal samples were collected before the first colonic irrigation and at 1 week after the third irrigation. These samples were analyzed using a kit from TechnoSuruga Laboratory Co., Ltd. (Shizuoka Japan). Fecal microbiota analysis targeted bacterial 16S rRNA genes with a terminal restriction fragment length polymorphism (T-RFLP) analysis program (Nagashima's method) (Ando et al., 2007; Nagashima et al. 2002, 2006). T-RFLP was performed as previously described by Nagashima et al. (2002, 2006). The 16S rRNA genes were amplified using a forward primaer, 516f [5'-TGCCAGCAGCCGCGGTA-3'] and a reverse primer, 1510r [5'-GGTTACCTTGTTACGACTT-3']. The $5^{\prime}$ ends of the forward primer, $516 \mathrm{f}$ were labeled with $6^{\prime}$-carboxyfluorescein, which was synthesized by Applied Biosystems Japan (Tokyo, Japan). The purified PCR products $(2 \mu \mathrm{L})$ were digested with $10 \mathrm{U}$ of either BsII (New England BioLabs, Inc., Ipswich, MA, USA) at $55^{\circ} \mathrm{C}$ for $3 \mathrm{~h}$. The lengths of terminal restriction fragments were determined with the ABI PRISM 3130xl Genetic Analyzer (Applied Biosystems, Tokyo, japan).

\subsection{Laboratory determinations}

Blood samples were collected from the subjects in a sitting position before the start and at 10 min after the third irrigation. Serum samples were analyzed using a commercial kit.

\subsection{Colonic irrigations}

Each patient underwent 3 colonic irrigations over a period 2 weeks. Same trained physician performed colonic irrigations for all subjects. Irrigations using an intestinal irrigation devide (Colon Hydromat Comfort: Herrmann Apparatebau GmbH, Kleinwallstadt, Germany) that circulated approximately $30-50 \mathrm{~L}$ of purified warm water $\left(38^{\circ} \mathrm{C}\right)$ through a filter (UchiyamaTanaka, 2009). During an irrigation process, which lasts for approximately 1 hour, a subject is laid supine on a bed and given abdominal massage. Because colonic irrigations utilize a large amount of water introduced using a tube and abdominal massage, there are some contraindications, such as renal failure, heart failure, liver cirrhosis, severe hemorrhoids, after post-intestinal polypectomy, post-abdominal surgery and pregnacy. The principle of the Colon Hydromat Comfort's function is shown in Figure1.

Filtered hot water and ordinary water are mixed and passed into a patient's colon through the speculum. The sewage water flows out due to the pressure in the water-filled colon. Some pictures of fecal residues and intestinal epithelium during colon irrigations are shown below.

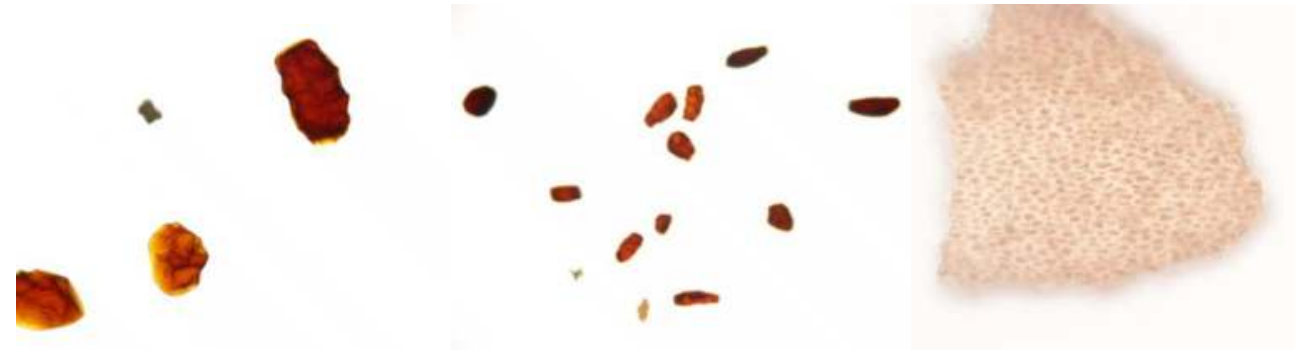




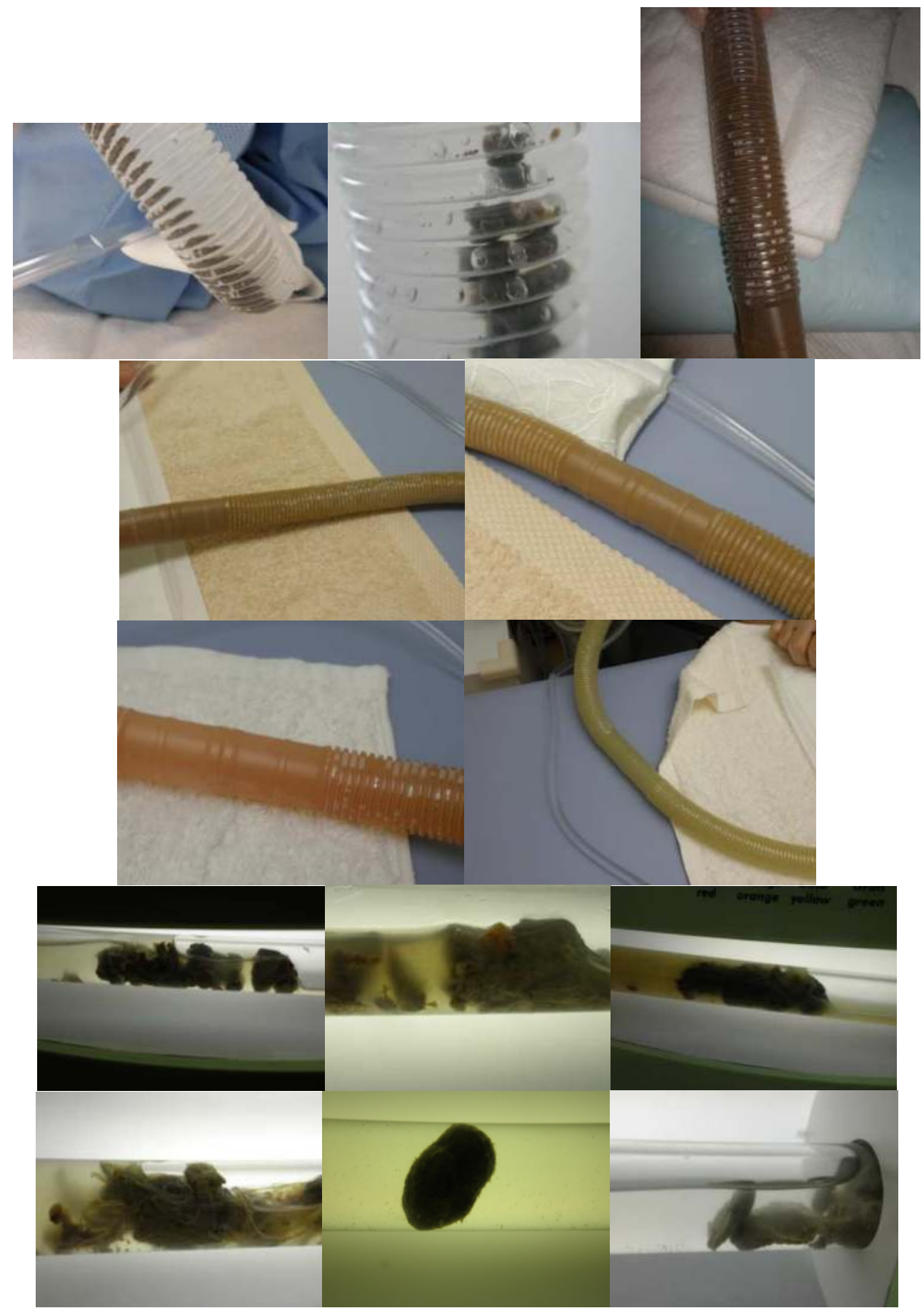



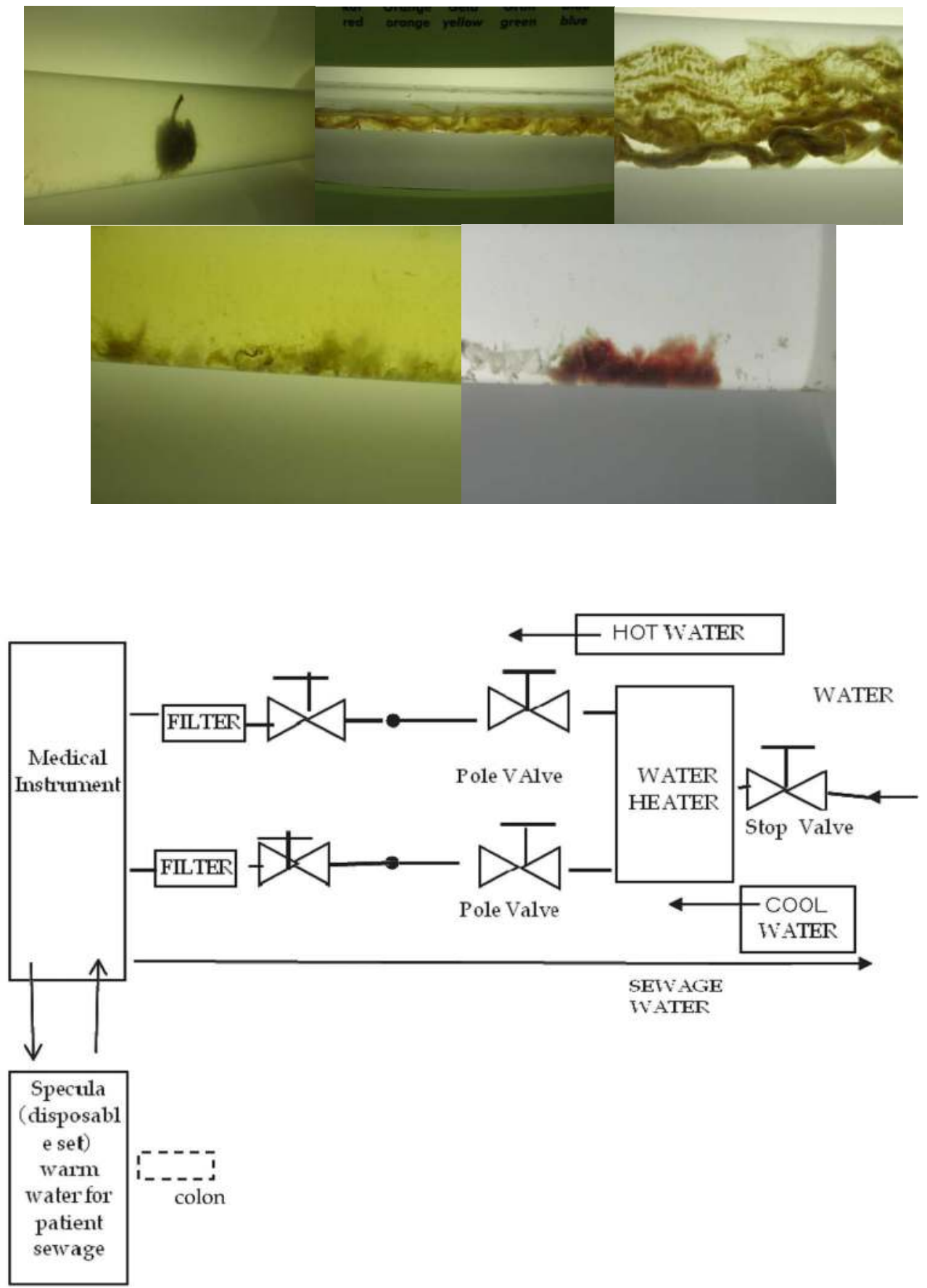

Fig. 1. Principle of the Colon Hydromat Comfort 


\subsection{Statistics}

Results are given as means \pm standard deviations (SD). Student's paired $t$-test was used to compare results before and after irrigations. $\mathrm{P}<0.05$ was considered statistically significant.

\section{Results}

Patient clinical characteristics are summarized in Table 1.

\begin{tabular}{|c|c|c|l|l|}
\hline Patient & Age & Gender & Underlying disease & \multicolumn{1}{|c|}{ Symptom change } \\
\hline No. 1 & 44 & Male & Pollen allergy & Symptom-free (after 7 times) \\
\hline No. 2 & 47 & Female & Constipation & Better \\
\hline No. 3 & 45 & Female & Ovarian cysts & $\begin{array}{l}\text { Size Smaller }(8 \mathrm{~cm} \text { to } 6 \mathrm{~cm} \text {, after } \\
\text { 3times })\end{array}$ \\
\hline No. 4 & 47 & Male & Atopic dermatitis & Decreased itching \\
\hline No. 5 & 28 & Male & Psoriasis & $\begin{array}{l}\text { Better (still undergoing } \\
\text { irrigation) }\end{array}$ \\
\hline No. 6 & 38 & Female & Constipation & Better \\
\hline No. 7 & 38 & Female & Constipation & Better \\
\hline No. 8 & 32 & Female & Face eruption & Better \\
\hline No. 9 & 39 & Female & Constipation & Better \\
\hline No. 10 & 29 & Male & Allergic Rhinitis & Decreased blowing of nose \\
\hline
\end{tabular}

Table 1. Subject's clinical characteristics and symptom changes after irrigations

Each patient underwent 3 colonic irrigations over a period of 2 weeks. Fecal samples were collected before the first colon irrigation and at 1 week after the third irrigation. The relative proportions of bacteria found in the fecal samples of each patient before and after colonic irrigation are shown in Table 2.

\begin{tabular}{lcccccccc} 
& 1 & & 2 & & 3 & & 4 & \\
\hline Presumed bacterium & $\mathrm{b}$ & $\mathrm{a}$ & $\mathrm{b}$ & $\mathrm{a}$ & $\mathrm{b}$ & $\mathrm{a}$ & $\mathrm{b}$ & $\mathrm{a}$ \\
\hline Bifidobacterium & 18.6 & 16.5 & 22.9 & 17.1 & 8.7 & 14.9 & 1.8 & 14.5 \\
Lactobacillales & 2.2 & 4.5 & 4.1 & 0 & 6.1 & 4 & 0 & 0 \\
Bacteroides & 23 & 17 & 21.3 & 20.9 & 31.7 & 31.6 & 44.4 & 38.3 \\
Prevotella & 9.1 & 2.8 & 7.8 & 8.9 & 0 & 0 & 0 & 0 \\
Clostridium cluster IV & 11.6 & 15.4 & 14.5 & 19.1 & 25.5 & 23 & 22.7 & 13.9 \\
Clostridium subcluster XIVa & 13 & 16.3 & 17.7 & 24.7 & 21.3 & 19.4 & 14.6 & 22.4 \\
Clostridium cluster XI & 2.6 & 4.2 & 0 & 0 & 0 & 0 & 2.4 & 2.3 \\
Clostridium cluster XVIII & 7 & 4.4 & 2 & 1.4 & 0 & 0 & 5.1 & 0 \\
others & 13 & 18.8 & 9.6 & 8 & 6.7 & 7.1 & 9.1 & 8.6 \\
\hline
\end{tabular}

Table 2. Continued 


\begin{tabular}{cccccccccccc}
5 & & 6 & & 7 & & 8 & & 9 & & 10 & \\
\hline $\mathrm{b}$ & $\mathrm{a}$ & $\mathrm{b}$ & $\mathrm{a}$ & $\mathrm{b}$ & $\mathrm{a}$ & $\mathrm{b}$ & $\mathrm{a}$ & $\mathrm{b}$ & $\mathrm{a}$ & $\mathrm{b}$ & $\mathrm{a}$ \\
\hline 1.9 & 2 & 17.9 & 2.6 & 22.6 & 28.2 & 9.9 & 1 & 0 & 28.5 & 5.6 & 26.7 \\
0 & 0 & 1.5 & 0 & 2.7 & 2.5 & 0 & 0 & 3.3 & 3.2 & 1.6 & 1.5 \\
28.3 & 14.7 & 13.5 & 14.4 & 15.6 & 25.4 & 29.8 & 12.3 & 59.8 & 30.3 & 32.9 & 33 \\
38.3 & 31.6 & 23.9 & 30.3 & 0 & 0 & 0 & 40.3 & 0 & 0 & 0 & 0 \\
2.8 & 8.1 & 3.8 & 1.5 & 12.6 & 11.7 & 0 & 19.7 & 0 & 19.1 & 0 & 4.8 \\
3.9 & 15.8 & 19 & 11.2 & 22.8 & 17.4 & 26.5 & 11.6 & 7.7 & 13 & 24.4 & 15.1 \\
1.7 & 0 & 1 & 3.4 & 11.1 & 3 & 13.8 & 2.5 & 3.3 & 3.3 & 0 & 0 \\
1.1 & 0 & 1.1 & 0.6 & 0 & 1.5 & 0 & 1.2 & 1.7 & 0 & 0 & 0 \\
22 & 27.8 & 18.3 & 35.9 & 12.6 & 10.3 & 20 & 11.3 & 24.3 & 2.4 & 35.5 & 18.9 \\
\hline
\end{tabular}

No 1-10: Patients in Table 1. b: Before colonic irrigations. a: After 3 times colonic irrigations

Table 2. The changes in the fecal microbiota between prior to and after 3 clonic irrigations

There were no significant differences in the overall quantities of fecal bacteria in samples collected before and after irrigations. There was also no tendency for changes int the proportions of Lactobacillales and Bifidobacterium and Clostridium subclusters. The proportions of these bacterial orders are shown in Table 3.

\begin{tabular}{|c|c|c|c|}
\hline Presumed microbiota $\%$ & prior to $($ mean \pm SD) & after & $\mathrm{p}$ \\
\hline Bifidobacterium & $10.99 \pm 8.85$ & $15.29 \pm 10.74$ & $\mathrm{p}>0.05$ \\
\hline Lactobacillales & $2.15 \pm 1.99$ & $1.57 \pm 1.84$ & $\mathrm{p}>0.05$ \\
\hline Bacteroids & $30.08 \pm 13.86$ & $23.8 \pm 9.2$ & $\mathrm{p}>0.05$ \\
\hline Prevotella & $7.88 \pm 13.07$ & $11.39 \pm 16.09$ & $\mathrm{p}>0.05$ \\
\hline Clostridium IV & $9.4 \pm 9.62$ & $13.62 \pm 7.04$ & $\mathrm{p}>0.05$ \\
\hline Clostridum XIVa & $17.07 \pm 7.33$ & $16.64 \pm 4.42$ & $\mathrm{p}>0.05$ \\
\hline Clostridum XI & $3.61 \pm 4.9$ & $1.87 \pm 1.69$ & $\mathrm{p}>0.05$ \\
\hline Clostridum XVIII & $1.8 \pm 2.4$ & $0.91 \pm 1.38$ & $\mathrm{p}>0.05$ \\
\hline Others & $17.13 \pm 8.85$ & $14.92 \pm 10.42$ & $\mathrm{p}>0.05$ \\
\hline
\end{tabular}

Table 3. The mean changes in the microbiota between prior to and after 3 colonic irrigations

According to Collins et al. (1994), Clostridium clusters and subclusters cannot revide the unknown pole in intestine. For example, Faecalibacterium prausnitzil is an important bacteria as butyrate-producing bacterium in Clostridium cluster IV. In contrast, Clostridium perfringens is a well known as harmful bacterium in Clostridium cluster I. Lactobacillales and Bifidobacterium are considered to be healthy, beneficial fecal bacteria. In this study, beneficial bacteria decreased in some patients. Serum electrolytes after irrigations (sodium, potassium, and chlorine) exhibited no significant changes from their values before irrigation (data not shown). Patient symptoms were improved after irrigations (Table 1), and they did not experience any difficulties. 


\section{Discussion}

This study showed that colonic irrigations are safe in terms of serum electrolytes for subjects with normal renal function and had a positive impact on these subjects' symptoms. However, these irrigations showed no tendency for any effects on the intestinal microbiota. Colonic irrigation was developed at the National Aeronautics and Space Administration and has been used worldwide in the care of allergic and pollen diseases, skin disorders, and constipation. I previously reported that colonic irrigation may induce lymphocyte transmigration from GALT into the circulation, which may improve the function of both the colon and the immune system functions (Uchiyama-Tanaka, 2009). The increase in the lymphocytes was suspected to be the result of lymphocytes transmigrating as intraepithelial lymphocytes from Peyer's patched and lymph nodes around the intestine as a result of irrigation and abdominal massage.

Based on my personal experience, patient symptoms can improve after colonic irrigations. However, it has been proposed that colon irrigations with large volumes of water may obliterate the microbiota and induce electrolyte abnormalities, but no studies support these claims. The results of this study suggests that after 3 s colonic irrigations, the composition of the microbiota changes, but there is no tendency for the changes in the bacterial components.

Colonic irrigations are different from enemas for the following reasons: (a) they are not selfadministered, but are administered by a professionally trained person; and (b) they are administered using a device that controls water flow and infuses the entire colon with water, in contrast to the more limited infusion of warm filtered water into the rectum. The water circulates throughout the colon and removes its contents while the patient lies on a bed. The temperature and pressure of water are closely monitored and regulated during a series of fills and releases to aid colonic peristalsis. Because this method involves a closed system, the waste materials are removed without any unpleasant odor or discomfort, which are usually associated with enemas.

The intestine is an important site of local immunity and nutrition (Iiai et al., 2002). It is a major site of extrathymic $\mathrm{T}$ cell differentiation, and numerous activated and quiescent lymphocytes are produced within GALT. The very important role of the intestine, as a part of the immune system is due to the intestinal microbiota. Thus, it has been speculated in peoplewho suffer from constipation and who harbor fecal residues, the intestine may have a diminished function in the immune system (Alveres, 2001, 1924).

The intestinal epithelium is the first line of defense system to encounter intestinal pathogens and dietary antigens. It has been speculated that when the intestine is filled with feces, there may be a reduced function of this immune system caused by toxins leaking from the gut, in addition to bacterial translocation from the gut to the systemic circulation caused by a breakdown of the intestinal wall. This breakdown can be caused by a variety of injuries to the body at further locations far from the gut.

It has been reported that increased gut permeability and bacterial translocation play a role in multiple organ failure (MOF: Swank \& Deitch, 1996). Failure of the gut barrier is central to the hypothesis that toxins escaping from the gut lumen contribute to the activation of a host's immune inflammatory defense mechanisms, which subsequently leads to auto- 
intoxication and tissue destruction that are seen in the septic response characteristics of MOF (Swank \& Deitch,1996; Garcia-Tsao et al., 1995; Purohit et al., 2008). Thus, colonic irrigation is useful for removing fecal residues.

Although irrigation is useful for establishing a "good" status in the intestine in terms of removing fecal residues, we should not expect too much from these irrigations. Factors like proper nutrition and food intake and a stress-free life style are also important in improving the microbiota, rather than colonic irrigations alone. One report showed that the microbiota of people on a strict vegetarian diet was very different from those on normal diets (Hayashi et al. 2002b). The removal of residual fecal matter in the colon may provide a break from a bad dietary cycle and highlight the importance of intestinal care in everyday life.

Colonic irrigation is relatively safe and is a good method for impressing upon patients the importance of intestinal care. But according to the results of this study, some patients' microbiota deteriorated. Although safe in terms of serum electrolytes, it should be noted that colonic irrigations should not be performed for patients with renal failure, heart disease, liver cirrhosis with ascites, recent abdominal surgery, pregnancy, and other conditions. In addition, excessive therapy such as everyday irrigations should be avoided. This may result in the loss of massive amount of digestive fluid. Except for the first 3 times of colonic irrigation, subsequent irrigations should be performed within a minimum 1 month interval.

This study was limited by its small study population. Some subjects showed reduced proportions in beneficial fecal bacteria, although their symptoms including allergic rhinorrhea, constipation, skin itching, and eczema, were improved. We should be careful with regard to the duration and number of irrigations administered and preferably take probiotics after colonic irrigation. If the patient is in a "good" status in terms of stool analysis, a single trial with an adequate duration would be sufficient.

Another limitation of this study was that the actual numbers of bacteria were not determined using these methods. T-RFLP is only useful for estimating the proportions of bacteria. Hence, we need a more efficient quantitative method for bacterial analysis in addition to the existing one with an advantageous cost versus performance.

In conclusion, colonic irrigation has no influence on serum electrolytes and may induce improvements in symptoms without any effects on the intestinal microbiota.

\section{References}

Alveres, WC. (2001). Origin of so-called autointoxication symptoms. JAMA.72: pp. 8-13.

Alverez, WC.; Freedlander. BL.(1924). The rate of progress of food residues through the bowel. JAMA. 83: pp. 576-580.

Ando, A.; Sakata, S., Koizumi, Y., Mitsuyama, K., Fujiyama, Y., Benno, Y.(2007). Terminal restriction fragment length polymorphism analysis of the diversity of fecal microbiota in patients with ulcerative colitis. Inflamm Bowel Dis. 13: pp. 955-962.

Cerf-Bensussan, N.; Guy-Grand, D., Griscelli, C. (1985). Intraepithelial lymphocytes of human gut: isolation, characterization and study of natural killer activity. Gut. 26: pp.81-88 
Collins, MD.; Lawson, PA., Willems ,A., Cordoba, JJ., Fernandez-Garayzabal, J., Garcia, P., Cai, J., Hippe, H., Farrow, JAE.(1994). The Phylogeny of the Genus Clostridium: Proposal of Five New Genera and Eleven New Species Combinations. Int J Syst Bacteriol. 44: pp. 812-826.

Garcia-Tsao, G.; Lee, FY., Bardeb, GE., Cartun, R., West, AB. (1995) Bacterial translocation to mesenteric lymph nodes is increased in cirrhotic rats with ascites. Gastroenterology 108: pp. 1835-1841

Guy-Grand, D.; Cerf-Bensussan, N., Malissen, B., Malassis-Seris ,M., Briottet, C., Vassalli, P. (1991). Two gut intraepithelial CD8+ lymphocyte population with different T cell receptors. A role for the gut epithelium in T cell differentiation. J Exp Med. 173: pp. 471-481.

Hayashi, H.; Sakamoto, M. \& Benno, Y. (2002). Phylogenetic analysis of human gut microbiota using $16 \mathrm{~S}$ rDNA clone libraries and strictly anaerobic culture-based methods. Microbiol Immunol, 46: pp. 535-548

Hayashi, H.; Sakamoto, M., Bennno, Y. (2002). Fecal microbial diversity in a strict vegetarian as determined by molecular analysis and cultivation. Microbiol Immunol 46: pp.819831.

Iiai, T.; Watanabe, H., Suda, T., Okamoto, H., Abo, T., Hatakeyama, K. (2002). CD161+T (NT) cells exist predominantly in human intestinal epithelium as well as in liver. Clin Exp Immunol 129: pp. 92-98.

Langendijk, PS.; Schut, F., Jansen, GJ., Raangs, GC., Kamphuius, GR., Wilkison ,MH., Welling, GW. (1995). Quantitative fluorescence in situ hybridization of Bifidobacterium spp. With genus-specific $16 \mathrm{~S}$ rRNA-targeted probes and its application in fecal samples. Appl Environ Microbiol 61: pp. 3069-3075

Moor, WE.; Holdeman, LV.(1974). Human fecal flora: the normal flora of 20 JapaneseHawaiians. Appl Environ Microbiol. 27: pp. 961-979

Nagashima, K.; Hisada ,T., Sato, M., Mochizuki, J. (2002). Application of new primerenzyme combinations to terminal restriction fragment length polymorphism profiling of bacterial populations in human feces. Appl Environ Microbiol 69: pp. 1251-1262

Nagashima, K.; Mochizuki, J., Hisada, T., Suzuki, S., Shimomura, K. (2006). Phylogenetic analysis of $16 \mathrm{~S}$ ribosomal RNA gene sequences from human fecal microbiota and improved utility of terminal restriction fragment length polymorphism profiling. Bioscience Microflora. 25: pp. 99-107.

Purohit, V.; Bode, JC., Bode, C., Brenner, DA., Choudhry, MA., Hamilton, F., Kang, YJ., Keshavarzin, A., Rao, R., Sartor, RB., Swanson, C., Turner, JR. (2008) Alcohol, intestinal bacterial growth, intestinal permeability to endotoxin, and medical consequences: Summary of a symposium. Alcohol 42: pp. 349-361

Suau, A.; Bonnet, R., Sutren, M., Godon, JJ., Gibson, G.R., Collins, MD., Dore, J. (1999). Direct analysis of genes encoding 16S rRNA from complex communities reveals many novel molecular species within the human gut. Appl Environ Microbiol 65: pp. 4799-4807

Swank, GM.; Deitch, EA. (1996) Role of the gut in multiple organ failure. Bacterial translocation and permeability changes. World J Surg 20: pp. 411-417

Takahashi, S.; Kawamura ,T., Kanda, Y., Taniguchi, T., Nishizawa, T., Iiai, T., Hatakeyama, K., Abo, T.(2005). Multipotential acceptance of Peyer's patches in the intestine for 
both thymus-derived T cells and extrathymic T cells in mice. Immunol Cell Biol. 83: pp.504-510.

Uchiyama-Tanaka, Y.; (2009). Colon irrigation and lymphocyte movement to peripheral blood. Biochemical Research. 30:pp. 311-314.

Van der Waaij, D.; Berghuis-de Vries, JM., Lekkerkerk van der ,Wees. (1971). Colonization resistance of digestive tract in conventional and antibiotic treated mice. J Hyg. 67: pp. 405-411. 


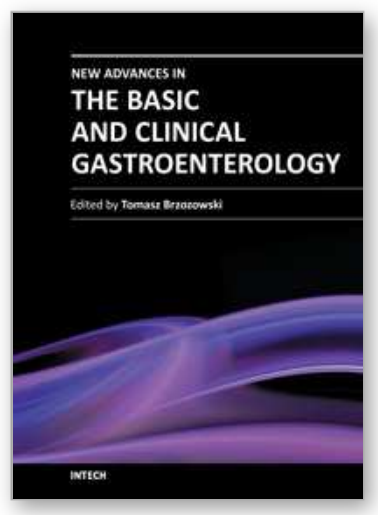

\author{
New Advances in the Basic and Clinical Gastroenterology \\ Edited by Prof. Tomasz Brzozowski
}

ISBN 978-953-51-0521-3

Hard cover, 546 pages

Publisher InTech

Published online 18, April, 2012

Published in print edition April, 2012

The purpose of this book was to present the integrative, basic and clinical approaches based on recent developments in the field of gastroenterology. The most important advances in the pathophysiology and treatment of gastrointestinal disorders are discussed including; gastroesophageal reflux disease (GERD), peptic ulcer disease, irritable bowel disease (IBD), NSAIDs-induced gastroenteropathy and pancreatitis. Special focus was addressed to microbial aspects in the gut including recent achievements in the understanding of function of probiotic bacteria, their interaction with gastrointestinal epithelium and usefulness in the treatment of human disorders. We hope that this book will provide relevant new information useful to clinicians and basic scientists as well as to medical students, all looking for new advancements in the field of gastroenterology.

\title{
How to reference
}

In order to correctly reference this scholarly work, feel free to copy and paste the following:

Yoko Uchiyama-Tanaka (2012). The Influence of Colonic Irrigation on Human Intestinal Microbiota, New Advances in the Basic and Clinical Gastroenterology, Prof. Tomasz Brzozowski (Ed.), ISBN: 978-953-51-05213, InTech, Available from: http://www.intechopen.com/books/new-advances-in-the-basic-and-clinicalgastroenterology/the-influence-of-colon-irrigation-on-human-intestinal-microbiota

\section{INTECH}

open science | open minds

\author{
InTech Europe \\ University Campus STeP Ri \\ Slavka Krautzeka 83/A \\ 51000 Rijeka, Croatia \\ Phone: +385 (51) 770447 \\ Fax: +385 (51) 686166 \\ www.intechopen.com
}

\author{
InTech China \\ Unit 405, Office Block, Hotel Equatorial Shanghai \\ No.65, Yan An Road (West), Shanghai, 200040, China \\ 中国上海市延安西路65号上海国际贵都大饭店办公楼 405 单元 \\ Phone: +86-21-62489820 \\ Fax: +86-21-62489821
}


(C) 2012 The Author(s). Licensee IntechOpen. This is an open access article distributed under the terms of the Creative Commons Attribution 3.0 License, which permits unrestricted use, distribution, and reproduction in any medium, provided the original work is properly cited. 